\title{
Peningkatan Kemampuan Pembukuan Pada Ukm Bakmi Pak Gembong
}

\author{
Febrina Nafasati Prihantini ${ }^{1}$, Dian Indudewi ${ }^{2}$, Alfa Vivianita ${ }^{3}$ \\ Universitas Semarang ${ }^{1,2,3}$ \\ febrina@usm.ac.id
}

\begin{abstract}
One of the characteristics of small industries is that they still face many obstacles, both in terms of production and business management. The production aspect includes technology/equipment, production continuity, quality uniformity, packing, labeling, etc., while in the business management aspect there is not much support for promotions, marketing development strategies, and limited distribution and bookkeeping of business results. The same thing happened to Bakmi Pak Gembong who was in Rejosari Village, East Semarang District. Where Pak Gembong's Bakmi Business is still a small-scale industry that also has problems in terms of management, especially in terms of recording the results of its business. To overcome these problems, Community Service activities were carried out by providing counseling about the importance of recording all matters relating to the operation of a business. The expected outcome of this Community Service activity is that SME actors have an understanding of the importance of recording their business on a regular basis and the benefits derived from recording business operations on a regular basis.
\end{abstract}

Keywords: Listing, Business Operations, UKM

\begin{abstract}
Abstrak
Salah satu ciri khas dari industri kecil adalah masih banyak kendala yang dihadapi ini baik dari aspek produksi maupun manajemen usahanya. Pada aspek produksi antara lain teknologi/peralatan, kontinyuitas produksi, keseragaman kualitas, packing, labeling, dll, sedangkan pada aspek manajemen usahanya adalah belum banyak dilakukan dukungan promosi, strategi pengembangan pemasaran, serta distribusi yang terbatas dan pembukuan atas hasil usahanya. Begitu pula yang dialami oleh Bakmi Pak Gembong yang berada di Kelurahan Rejosari Kecamatan Semarang Timur. Dimana Usaha Bakmi Pak Gembong masih merupakan industri skala kecil yang juga memiliki kendala dalam hal manajemen, khususnya dalam hal pencatatan hasil usahanya. Untuk mengatasi permasalahan tersebut maka dilaksanakan kegiatan Pengabdian Bagi Masyarakat dengan memberikan penyuluhan mengenai pentingnya melakukan pencatatan semua hal yang berkaitan dengan operasional suatu usaha. Luaran yang diharapkan dari kegiatan Pengabdian
\end{abstract}


Masyarakat ini adalah pelaku UKM memiliki pemahaman pentingnya melakukan pencatatan atas usahanya secara rutin dan manfaat yang diperoleh dari pencatatan operasional usaha yang dilakukan secara rutin.

\section{Kata Kunci : Pencatatan, Operasional Usaha, UKM}

\section{PENDAHULUAN}

Sejalan dengan perkembangan dunia usaha, banyak berdiri bentuk-bentuk usaha baik yang berskala kecil, menengah sampai berskala besar. Usaha Kecil dan Menengah (UKM) merupakan salah satu kekuatan pendorong terdepan dalam pembangunan ekonomi. Gerak sektor UKM amat vital untuk menciptakan pertumbuhan dan lapangan pekerjaan.UKM cukup fleksibel serta dapat dengan mudah beradaptasi dengan pasang surut dan arah permintaan pasar.Mereka juga menciptakan lapangan pekerjaan lebih cepat dibandingkan dengan sektor usaha lainnya, dan mereka cukup terdiversifikasi serta memberikan kontribusi penting dalam ekspor dan perdagangan (Saragih \& Surikayanti, 2015).

Akuntansi merupakan kunci indikator kinerja usaha. Informasi yang disediakan oleh catatan-catatan akuntansi berguna bagi pengambilan keputusan sehingga dapat meningkatkan pengelolaan perusahaan.Informasi-informasi tersebut memungkinkan para pelaku UKM dapat mengidentifikasi dan memprediksi area-area permasalahan yang mungkin timbul, kemudian mengambil tindakan koreksi tepat waktu. Walaupun dampak dari diabaikannya pengelolaan keuangan mungkin tidak terlihat secara jelas, namun tanpa implementasi akuntansi yang efektif, usaha yang memiliki prospek yang cerah dapat menjadi bangkrut. Melalui penerapan akuntansi yang baik, diharapkan sebuah UKM dapat mengetahui bagaimana perkembangan dan kesehatan usahanya. berapa keuntungan yang diperoleh usahanya pada suatu periode tertentu (Saragih \& Surikayanti, 2015). Sepanjang UMKM masih menggunakan uang sebagai alat tukarnya maka akuntansi sangat dibutuhkan oleh UMKM (Sugeng et al., 2021).

Penggunaan akuntansi dapat mendukung kemajuan UMKM khususnya dalam hal keuangan. Peningkatan laba juga dapat direncanakan dengan menggunakan akuntansi. Dengan tingkat laba yang semakin meningkat, perkembangan UMKM akan menjadi lebih baik sehingga UMKM akan benar-benar menjadi salah satu solusi bagi masalah perekonomian di Indonesia. Namun, masih banyak UMKM yang belum menggunakan akuntansi dalam menunjang kegiatan bisnisnya. Alasan pelaku UMKM tidak menggunakan akuntansi antara lain adalah akuntansi dianggap sesuatu yang sulit dan tidak penting (Irawati et al., 2019; Sugeng et al., 2021).

Hal ini pula yang dialami oleh Bakmi Pak Gembong yang berada di Kelurahan Rejosari Kecamatan Semarang Timur. Bakmi Pak Gembong adalah usaha warung makan yang sudah berdiri sejak tahun 1976. Pemilik Usaha Ibu Puji Rahayu adalah generasi ke 3 dari usaha Bakmi Pak Gembong. Yang dijual dari usaha warung makan ini adalah makanan dan minuman. Sistem penjualan dilakukan secara tunai dan melalui pesanan online gofood, grabfood dan shopeefood. Menempati sebuah bangunan yang merupakan milik sendiri dimana omzet penjualan sehari yang diperoleh sebesar Rp. 2.000.000. 
Bakmi Pak Gembong adalah industri berskala kecil dan merupakan industri yang memiliki banyak pesaing. Dengan adanya banyak pesaing maka Bakmi Pak Gembong harus memperhatikan manajemen usahanya agar dapat bersaing. Pengelolaan manajemen usaha terutama dalam hal pengelolaan keuangan harus mendapatkan perhatian utama. Hal ini karena dengan pengelolaan keuangan yang baik UKM dapat mengetahui mengenai perkembangan usahanya. Dari sini Bakmi Pak gembong dapat mengambil keputusan yang berhubungan dengan perkembangan usahanya seterusnya.

Pengelolaan keuangan menjadi suatu masalah dalam UKM karena biasanya pemilik UKM mengabaikan pentingnya pengelolaan keuangan. Karena bisnis UKM yang keuangannya dikelola dan diinformasikan secara transparan dan akurat akan memberikan dampak positif terhadap bisnis UKM itu sendiri (Ediraras, 2010). Namun pada kenyataannya masih ada UMKM yang belum mampu mengelola usahanya dengan baik, sehingga tidak jarang pula UMKM yang gagal dalam usahanya. Kegagalan ini disebabkan karena masih rendahnya pengetahuan pemilik UMKM akan pengelolaan usaha. Pengelolaan usaha yang perlu diperhatikan adalah pengelolaan dalam bidang keuangan (Setyaningrum, 2019). Menurut Srikandi dan Setyawan (2004), yang dikutip oleh (Setyaningrum, 2019) bahwa masalah yang sering dihadapi pemilik UMKM adalah dalam bidang pemasaran produk, teknologi, kualitas sumber daya manusia, dan pengelolaan keuangannya. Pengelolaan keuangan menjadi suatu masalah dalam UMKM karena pemilik UMKM mengabaikan pentingnya pengelolaan keuangan.

Para Pelaku UMKM memandang bahwa proses akuntansi tidak terlalu penting untuk diterapkan dan banyak diantara mereka yang belum memahami pentingnya pencatatan dan pembukuan bagi kelangsungan usahanya. Sehingga berdasarkan kondisi ini perlu dilakukannya pelatihan mengenai pembukuan secara sederhana dengan menggunakan buku kas dan mengevaluasi perhitungan harga pokok produksi pada Bakmi Pak Gembong.

Adapun tujuan dari pelaksanaan pengabdian masyarakat ini adalah untuk memberikan pengetahuan kepada pelaku UKM mengenai pentingnya melakukan pengelolaan keuangan melalui pencatatan hasil usahanya. Sedangkan Manfaat dari pelaksanaan pengabdian amsyarakat ini adalah pelaku UKM memiliki pengetahuan mengenai pengelolaan keuangan dan kesadaran pentingnya melakukan pencatatan atas hasil usahanya secara rutin.

Berdasarkan penjelasan pada analisis situasi maka permasalahan mitra terfokus pada belum adanya pencatatan operasional usahanya secara rutin. Pencatatan usaha diperlukan agar pemilik usaha dapat mengetahui perkembangan usahanya. Dengan tidak adanya pencatatan mengenai operasional usaha yang dilakukan secara rutin maka pemilik usaha akan kesulitan untuk mengetahui bagaimana kodisi usahanya dengan segera. Pemilik UKM yang mengetahui kondisi usahanya dapat dengan segera mengambil keputusan berkaitan dengan usahanya.

Adapun tujuan dari pelaksanaan pengabdian masyarakat ini adalah untuk memberikan pengetahuan kepada pelaku UKM mengenai pentingnya melakukan pengelolaan keuangan melalui pencatatan hasil usahanya. Manfaat dari pelaksanaan pengabdian masyarakat ini adalah pelaku UKM memiliki pengetahuan mengenai pengelolaan keuangan dan kesadaran pentingnya melakukan pencatatan atas hasil usahanya secara rutin.

Solusi yang ditawarkan untuk mengatasi permasalahan yang ada pada Bakmi Pak Gembong di Kelurahan Rejosari Kecamatan Semarang Timur yaitu memberikan penyuluhan mengenai pentingnya pengelolaan keuangan bagi UKM dengan melakukan pencatatan terhadap hasil usahanya yang dilakukan secara rutin. Target Luaran dari pelaksanaan pengabdian masyarakat pada Bakmi Pak Gembong di Kelurahan Rejosari Kecamatan Semarang Timur adalah target luaran di bidang manajemen yang yaitu para pelaku UKM memiliki pemahaman 
mengenai pentingnya pengelolaan keuangan usahanya melalui pencatatan secara rutin atas operasional usahanya.

\section{METODE}

Berdasarkan permasalahan yang dihadapi oleh para pelaku UKM Bakmi Pak Gembong di Kelurahan Rejosari Kecamatan Semarang Timur maka diajukan metode dalam pelaksanaannya yaitu :

\section{Persiapan}

Tahap persiapan terdiri dari :

a. Perencanaan waktu pelaksanaan pengabdian masyarakat dengan membuat jadwal pelaksanaan dengan pemilik UKM

b. Persiapan materi penyuluhan mengenai pencatatan sederhana dengan buku kas dan perhitungan harga pokok produksi

\section{Pelaksanaan}

Tahap pelaksanaan meliputi :

a. Dilakukannya penyuluhan mengenai pentingnya dilakukan pencatatan atau pembukuan atas operasional usahanya melalui bentuk tanya jawab dengan pelaku UKM Bakmi Pak Gembong.

b. Dilakukannya penyuluhan mengenai komponen apa saja yang harus diperhitungkan dalam menghitung harga pokok produksi melalui bentuk tanya jawab dengan pelaku UKM Bakmi Pak Gembong.

\section{HASIL DAN PEMBAHASAN}

Pelaksanaan Pengabdian Masyarakat dengan tema Pelatihan Pembukuan Sederhana pada UKM BAKMI PAK GEMBONG dilaksanakan pada Selasa, 19 Oktober 2021 pada pukul 10.00 sampai dengan 11.30. Materi yang diberikan adalah mengenai pembukuan sederhana dengan menggunakan buku kas dan komponen apa saja yang harus dimasukkan pada saat menghitung harga pokok produksi. Penyampian materi melalui presentasi dan diselingi dengan tanya jawab kepada pelaku UKM.

BAKMI PAK GEMBONG adalah usaha rumah tangga yang dilakukan oleh ibu rumah tangga yang bernama ibu Puji Rahayu. Dalam menjalankan usahanya Ibu Puji dibantu oleh 2 karyawan serta bantuan tenaga anggota keluarga yaitu suami dan Ibu Kandungnya. Ibu Puji Rahayu membuka usahanya mulai jam 5 sore sampai jam 12.00 malam. BAKMI PAK GEMBONG menjual makanan mie goreng dan nasi goreng beserta aneka minuman.

Menurut Undang-Undang No 28 Tahun 2007 tentang Ketentuan Umum Perpajakan (KUP), Pembukuan adalah suatu proses pencatatan yang dilakukan secara teratur untuk mengumpulkan data dan informasi keuangan yang meliputi harta, kewajiban, modal, penghasilan dan biaya, serta jumlah harga perolehan dan penyerahan barang atau jasa. yang ditutup dengan menyusun laporan keuangan yang terjadi dalam perusahaan (Ramdani et al., 2018). Selain itu Peraturan Menteri Koperasi dan UMKM juga mewajibkan kepada semua UMKM untuk menyelenggarakan laporan keuangan, karena tujuan laporan ini dapat dimanfaatkan oleh pihak internal ataupun eksternal (Ramdani et al., 2018). Berdasarakan UU No. 28 dan Peraturan Menteri Koperasi dan UMKM seharusnya UKM BAKMI PAK GEMBONG membuat setidaknya pembukuan yang digunakan untuk mencatat operasional usahanya. Hasil tanya jawab dengan Ibu Puji Rahayu diketahui : 
(1) Pemilik UKM tidak pernah melakukan pencatatan atas hasil usahanya. Baik itu pencatatan mengenai pengeluaran ataupun pencatatan atas hasil usahanya.

(2) Pemilik UKM hanya mengandalkan sistem deposit (simpanan) dalam menjalankan usahanya.

(3) Modal usahanya untuk berdagang satu hari beliau menyimpan uang (dalam satu tempat) sebesar Rp. 1.500.000. Dimana modal ini sudah termasuk pengeluaran untuk membeli bahan baku, membayar tenaga kerja dan biaya lainnya (listrik, gas dan air). Jika stok bahan baku belum habis maka modal sebesar Rp. 1.500.000 tidak digunakan semuanya. Sisa modal yang tidak digunakan tersebut tetap beliau simpan.

(4) Hasil penjualan dalam satu hari langsung dikurangi untuk membayar tenaga kerja yaitu 2 orang pegawai, 2 orang anggota keluarga dan dirinya sendiri.

(5) Hasil penjualan dalam satu hari juga sudah dikurangi modal yang telah dikeluarkan, dimana uang modal ini langsung disimpan ditempat yang sudah disiapkan khusus menyimpan uang modal berdagang.

(6) Sisa bersih hasil usahanya, beliau simpan ditempat yang sudah beliau siapkan khusus menyimpan laba hasil penjualannya. Dan beliau tidak melakukan pencatatan berapa laba bersih dari usahanya satu hari tersebut.

(7) Ketika Ibu Puji membutuhkan uang untuk keperluan perbaikan warungnya, keperluan pribadinya atau membayar utang, semuanya diambil dari sisa uang yang merupakan hasil besih dari usahanya tanpa melakukan pencatatan saat mengambilnya.

(8) Penjualan UKM BAKMI PAK GEMBONG juga dilakukan secara online melalui Grab, Gojek dan Shopee. Akan tetapi semua penerimaan penjualan yang berasal dari online pun tidak dicatat. Ibu Puji hanya melihat dari saldo Go Pay yang dimiliknya. Saldo ini dipergunakan untuk berbagai keperluan baik yang berhubungan dengan keperluan usahanya atau keperluan pribadinya tanpa melakukan pencatatan sama sekali.

Dalam dunia bisnis, persaingan antar perusahaan merupakan hal yang wajar. Setiap perusahaan berusaha menawarkan produk mereka dengan keunggulan masing-masing. Selain bersaing dalam hal kualitas, mereka juga bersaing dalam masalah harga, karena hanya produk dengan kualitas terbaik dan harga paling murah, yang paling diminati dan dicari oleh konsumen. Penetapan harga jual suatu produk, perusahaan terlebih dahulu harus menghitung harga pokok produksinya. Penentuan harga pokok yang tidak tepat juga akan mempengaruhi pengambilan keputusan oleh manajemen, misalnya keputusan untuk membuat atau membeli suatu produk, menerima atau menolak suatu pesanan khusus, dan menutup atau meneruskan suatu unit usaha (Alexandro \& Uda, 2020).

Salah satu permasalahan yang sering dihadapi oleh UKM adalah dalam menentukan harga jual produknya. Apabila UKM kurang teliti dan salah dalam menentukan harga pokok produksi maka dapat mengakibatkan ketidaktepatan dalam menentukan harga jual suatu produk. Harga jual yang terlalu tinggi akan menjadikan produk kurang bersaing di pasar, sementara harga jual yang terlalu rendah akan tidak memberikan keuntungan bagi pengusaha (Afdalia et al., 2020; Cinthya et al., 2019).

UKM BAKMI PAK GEMBONG merupakan salah satu UKM yang harus melakukan proses produksi terlebih dahulu agar dapat melakuakn penjualan. Adapun jalannya proses produksi di UKM BAKMI PAK GEMBONG : (1) Setiap hari Ibu Puji Rahayu akan mengecek stok bahan baku yang masih tersisa untuk menentukan apa saja yang harus beliau beli untuk persiapan berdagang satu hari itu, (2) Berdasarkan catat tersebut Ibu Puji melakukan pemesanan di malam hari baru kemudian mengambilnya keesokan harinya, (3) Proses produksi dimulai 
pukul 10 pagi sampai dengan jam 2 siang dan mulai menata usahanya jam 5 sore, (4) Jumlah porsi yang disediakan dalam satu hari adalah sebanyak kurang lebih 200 porsi.

Saat penentuan harga pokok produksi, informasi yang dibutuhkan oleh perusahaan adalah informasi mengenai biaya bahan baku, biaya tenaga kerja,dan biaya overhead pabrik (Mulyadi, 2007). Ketiga jenis biaya tersebut harus ditentukan secara cermat, baik dalam pencatatan maupun penggolongannya. Sehingga informasi harga pokok produksi yang dihasilkan dapat diandalkan, baik untuk penentuan harga jual produk maupun untuk perhitungan laba rugi periodik (Afdalia et al., 2020).

Untuk Perhitungan harga pokok produksi yang dilakukan oleh UKM BAKMI PAK GEMBONG adalah sebagai berikut : (1) Untuk komponen bahan baku dan komponen lainnya seperti tenaga kerja baik pegawai maupun anggota keluarga dan tenaga Ibu Puji sendiri sudah ikut diperhitungan dalam perhitungan harga pokok produsik termasuk biaya untuk listrik, gas dan air, karena modal yang Ibu Puji keluarkan sudah memperhitungkan semua komponen ini , (2) Akan tetapi sulit bagi Ibu Puji ketika harus menentukan berapa harga pokok satu porsi makanan dikarenakan tidak pernah menghitung dari jumlah bahan baku mie yang dia gunakan akan menghasilkan berapa porsi mie (baik goreng maupun tidak), begitupula dengan nasi goreng , (3) Penentuan harga jual satu porsi mie atau nasi goreng ditentukan berdasarkan kesepakatan antar sesama penjual yang menjual produk yang sama. Ketika terjadi kenaikan salah satu bahan baku maka mereka akan mengadakan pertemuan untuk membahas apakah akan menaikkan harga jual atau tidak, (4) Untuk bahan baku yang cepat basi tidak diperhitungkan oleh Ibu Puji, jadi saat jumlah porsi yang terjual kurang dari 200 porsi maka bahan baku yang cepat basi tersebut tidak digunakan lagi untuk berdagang keesokan harinya. Hal ini bisa dihindari jika Ibu Puji memiliki lemari pendingin sehingga bisa mengurangi kerugian akibat bahan baku yang cepat basi.

Berdasarkan tanya jawab dan pemberian materi mengenai pembukuan dan perhitungan harga pokok produksi diketahui : (1) Ibu Puji sebagai Pelaku UKM telah memiliki pemahaman bahwa perlu dilakukan pencatatan operasional usahanya terutama pencatatan untuk laba usahanya. Hal ini dikarenakan Ibu Puji mengakui terkadang bingung kemana saja keuntungan usahanya berkurang karena melihat ditempat penyimpanan uangnya sudah banyak berkurang dan lupa kemana saja uang itu digunakan. Walaupun sudah menerapkan sisten deposit dengan memisahkan keuntungan sendiri, tanpa membuat pencatatan maka pemilik UKM tidak dapat mengontrol dengan baik penggunaan keuntungan yang sudah diperolehnya. (2) Tidak dilakukannya pencatatan operasional usahanya oleh Ibu Puji berakibat Ibu Puji tidak memiliki informasi terkait berapa besarnya keuntungan yang telah diperoleh dan pengeluaran apa saja yang sudah dikeluarkan oleh Ibu Puji terkait dengan usahanya. Disamping itu Ibu Puji juga tidak bisa mengetahui pengeluaran apa saja yang tidak berhubungan dengan usahanya yang beliau ambil dari keuntungan usahanya. (3) Pelaku UKM juga memperoleh pemahaman bahwa perlu juga dilakukan pencatatan untuk pembelian bahan baku yang dapat distok. Karena dengan melakukan pencatatan mengenai stok, pemilik UKM dapat melakukan pembelian bahan tersebut dalam jumlah yang banyak dengan harga yang lebih murah, karena selama ini pemilik UKM hanya membeli untuk persediaan 3 hari saja kemudian membeli lagi dalam jumlah sedikit sesuai dengan jumlah yang sudah digunakan untuk berdagang sebelumnya. 


\section{KESIMPULAN}

Aplikasi pengingat minum obat berbasis offline yang terdapat di smartphone android dapat Kesimpulan dari pelaksanaan pengabdian masyarakat pada UKM BAKMI PAK GEMBONG adalah bahwa :

(1) Pemilik UKM hanya mengandalkan sistem deposit untuk modal dan keuntungan usahanya tanpa melakukan pencatatan sama sekali untuk setiap deposit yang dimiliki.

(2) Walaupun sudah menerapkan sistem deposit namun tanpa melakukan pencatatan sama sekali maka pemilik UKM tidak dapat mengetahui perkembangan usahanya dengan baik. Hal ini dapat terlihat pada pada Keuntungan usahanya. Pemilik UKM tidak dapat mengatur dengan baik penggunaan keuntungan usahanya. Jika dilakukan pencatatan dengan baik , walau itu hanya pencatatan berapa keuntungan yang dihasilkan dan digunakan untuk apa saja keuntungan tersebut, maka pemilik UKM bisa memanfaatkan keuntungan usahanya dengan baik. Salah pemanfaatan keuntungan adalah untuk investasi membeli lemari pendingin yang sangat dibutuhkan.

\section{DAFTAR PUSTAKA}

Afdalia, N., Totanan, C., \& Mile, Y. (2020). Analisis Penentuan Harga Pokok Produksi (Hpp) Pada Usaha Kecil Menengah (Ukm) Narasa Abadi Palu. Simak, 18(01), 47-57. https://doi.org/10.35129/simak.v18i01.113

Alexandro, R., \& Uda, T. (2020). Metode Perhitungan Harga Pokok Produksi Tahu pada UKM Krisna Karya Mulya di Palangka Raya. Jurnal Ilmiah Akuntansi Dan Humanika, 10(2), 195. https://doi.org/10.23887/jiah.v10i2.25263

Cinthya, L. N., Larasanty, L., Animah, A., \& Isnawati, I. (2019). Analisis Penentuan Harga Pokok Produksi Pada Usaha Kecil Menengah Sentra Pengrajin Bambu Pada Ukm Wahana Bambu Willis Gunung Sari Lombok Barat. JIAI (Jurnal Ilmiah Akuntansi Indonesia), 4(2), 89-106. https://doi.org/10.32528/jiai.v4i2.2657

Ediraras, D. (2010). Akuntansi Dan Kinerja Ukm. Jurnal Ilmiah Ekonomi Bisnis, 15(2), 152158. https://doi.org/10.35760/eb.

Irawati, W., Annisa, D., Aprilia, E. A., Utami, T., \& Angraini, D. (2019). Pengenalan dasarDasar Investasi bagi Ibu-Ibu PKK Kelurahan Babakan, Setu, Tangerang Selatan. ABDIMISI, 1(1), 18-23.

Ramdani, M. R., Kamidin, M., \& Ajmal, A. (2018). Implementasi SAK-ETAP Pada UMKM Warkop di Kota Makassar. Jurnal RAK (Riset Akuntansi Keuangan), 3(2), 0-19.

Saragih, F., \& Surikayanti. (2015). Analisis Penerapan Akuntansi dan Kesesuaiannya dengan SAK ETAP pada UKM Medan Perjuangan. Seminar Nasional Ekonomi Manajemen Dan Akuntansi (SNEMA) Fakultas Ekonomi Universitas Negeri Padang, 1, 452-461.

Setyaningrum, F. (2019). Strategi Laporan Keuangan Pada Usaha Mikro Kecil Dan Menengah. Optima, 2(2), 14. https://doi.org/10.33366/opt.v2i2.1164

Sugeng, A., Hasanah, N., Widiyati, D., Fitriyah, F., \& Afandi, A. (2021). Sosialisasi Laporan Keuangan UMKM dalam Rangka Membantu Program Kewirausahaan di Yayasan AlKhoiriyah. Abdimisi, 2(1), 15. https://doi.org/10.32493/abms.v2i1.4504 